\title{
Ekspresi Glukosa Transporter 2 Sel Beta Pankreas pada Tikus yang Diinduksi Streptozotocin dan Nikotinamid
}

\section{Expression of Glucose Transporter 2 of Beta Pancreatic Cells in Streptozotocin-Nicotinamide-Induced Rats}

\author{
Jena Hayu Widyasti ${ }^{1 *}$. \\ Fakultas Farmasi Universitas Setia Budi Surakarta \\ *email: jenahayu89@gmail.com
}

\begin{abstract}
ABSTRAK
Diabetes Melitus (DM) tipe II terjadi pada individu dengan resistensi insulin atau kerusakan sel $\beta$ pankreas sehingga tidak mampu merespon glukosa untuk menghasilkan insulin. Insulin merupakan hormon penting dalam transport glukosa. Glukosa transporter 2 (GLUT-2) pada membran sel $\beta$ pankreas bertanggung jawab pada transport glukosa yang akan menstimulasi sekresi insulin. Tujuan penelitian ini adalah untuk mengetahui ekspresi protein GLUT-2 pada sel $\beta$ pankreas tikus yang diinduksi Streptozotocin (STZ)-Nikotinamid (NA).

Penelitian menggunakan 2 kelompok tikus Wistar jantan. Kelompok I sebagai kontrol normal; kelompok II diinduksi STZ-NA. Dosis yang digunakan pada induksi STZ yaitu $50 \mathrm{mg} / \mathrm{kg}$ BB tikus dan NA $110 \mathrm{mg} / \mathrm{kg}$ BB tikus.Pengamatan ekspresi protein GLUT-2 sel $\beta$ pankreas tikus dilakukan secara imunohistokimia.

Hasil penelitian menunjukkan bahwa terjadi penurunan densitas GLUT-2 sel pada $\beta$ pankreas tikus yang diinduksi STZ-NA dibandingkan dengan kelompok tikus normal.

Kata kunci : GLUT-2, Induksi STZ-NA, DM
\end{abstract}

\section{ABSTRACT}

Diabetes Mellitus (DM) type II occurs in individual with insulin resistance or $\beta$ pancreatic cells damage which is not able to respond glucose and produce insulin. Insulin is an important hormon in glucose transport. Glucose transporter (GLUT-2) in $\beta$ pancreatic cell membranes is responsible for glucose transport that will stimulate insulin secretion. The purpose of this research was to the effectson GLUT-2 protein expression in pancreatic $\beta$ cells ofStreptozotocinNicotinamide-induced(STZ-NA) rats.

This research performed using two groups of male Wistar rats. Group I was normal control group, while Groups II were induced with STZ-NA. The dosage used in STZ induction is $50 \mathrm{mg} / \mathrm{kg}$ WB rats and NA $110 \mathrm{mg} / \mathrm{kg}$ WB rats. The expression of GLUT-2 protein in $\beta$ pancreatic cells in rats were observed by using immunohistochemistristy method.

The result showed that the density of GLUT-2 protein in $\beta$ pancreatic cells significantly decreased in the group STZ-NA-induced rats comparing to normal control group.

Key Word : GLUT-2, STZ-NA induced, DM

\section{PENDAHULUAN}

DM merupakan penyakit metabolik yang ditandai dengan hiperglikemia karena tubuh tidak dapat menghasilkan insulin atau terjadi peningkatan resistensi insulin. Hiperglikemia kronis dan gangguan metabolik lainnya pada DM dalam jangka panjang dapat menyebabkan kerusakan jaringan dan organ serta disfungsi yang melibatkan mata, ginjal, saraf dansistem vaskular (Cavallerano, 2009).DM tipe II terjadi pada individu dengan resistensi insulin dan kerusakan pada sel $\beta$ pankreas yaitu sel $\beta$ pankreas tidak mampu merespon 
glukosa untuk menghasilkan insulin. Insulin merupakan faktor penting dari transport glukosa. Kadar insulin yang tinggi dalam tubuh menyebabkan tidak adanya glikogenolisis dan merangsang penyerapan glukosa ke dalam otot, hati dan jaringan adiposa (Rose dan Ritcher, 2005). Glukosa transporter (GLUT-2) pada membran sel $\beta$ pankreas bertanggung jawab untuk transport glukosa yang akan menstimulasi untuk sekresi insulin (Othsubo et al., 2005), hal ini menyebabkan terjadi depolarisasi pada membran plasma karena penutupan kanal $\mathrm{K}^{+}$ATP dependent dan $\mathrm{Ca}^{2+}$ sehingga mensekresi granul insulin (Henquin et al., 2003).Ekspresi gen dari GLUT-2 dipengaruhi oleh kondisi metabolik dan juga jaringan tertentu. Ekspresi gen GLUT-2 dalam hati dan sel $\beta$ pankreas dipengaruhi oleh glukosa darah dan insulin. Dalam model hewan diabetes, tingkat GLUT 2 mRNA meningkat dalam hati (Rencurel, 1996), tetapi menurun dalam sel $\beta$ pankreas (Ohneda, 1993). Penelitian yang dilakukan oleh Ferrer et al. (1995) yaitu membandingkan ekspresi GLUT-2 pada manusia DM dan tanpa DM. Ekspresi GLUT-2 pada islet pankreas manusia DM tipe II lebih rendah dibandingkan dengan manusia yang tidak mengalami DM tipe II.

Penelitian ini bertujuan untuk membandingkan mengetahui ekspresi protein GLUT-2 pada sel $\beta$ pankreas tikus yang diinduksi STZ-NA.

\section{METODE PENELITIAN}

Dalam penelitian ini menggunakan tikus wistar jantan sebanyak 10 ekor dengan 2 kelompok perlakuan. Kelompok I sebagai kontrol normal (hanya diberi pakan pelet dan air), kelompok II diberikan induksi STZNA.

Induksi diabetes dilakukan dengan pemberian STZ dalam 0,1 M buffer sitrat $\mathrm{pH}$ 4,5 (Kulkarni et al., 2012). Pemberian NA dalam larutan saline. Menginduksi hewan uji menggunakan kombinasi STZ dengan dosis $50 \mathrm{mg} / \mathrm{kg}$ BB tikus dan NA dengan dosis $110 \mathrm{mg} / \mathrm{kg}$ BB tikus yang diberikan satu kali sehingga dapat menyebabkan DM dalam lima hari setelah induksi. NA diberikan 15 menit sebelum pemberian STZ. Induksi STZ dan NA diberikan secara intraperitoneal.

Prosedur Immunohistochemistry (IHC) dilakukan dengan tiga tahapan yaitu (1) preparasi slide sampel jaringan $\beta$ pankreas (2) optimasi pengenceran dan operating time antibodi antiGLUT-2, Immunohistochemistry (IHC) terhadap sampel, fotomikroskopi dan semikuantitatif densitas ekspresi protein GLUT-2.

\section{HASIL DAN PEMBAHASAN}

Pemeriksaan protein GLUT-2 dilakukan dengan menghitung secara semikuantitatif dari densitas warna cokelat pada sel $\beta$ pankreas tikus yang telah dilakukan pengecatan secara imunohistokimia dengan menggunakan antibodi antiGLUT-2. Foto hasil pengamatan dengan metode imunohistokimia dapat dilihat pada gambar 1. Hasil pengecatan GLUT-2 secara imunohistokimia pada sel $\beta$ pankreas yaitu ditunjukkan dengan warna cokelat pada daerah sitoplasma 
sel. Warna cokelat ditimbulkan karena adanya protein GLUT-2 pada sel $\beta$ pankreas yang mensekresikan insulin, yaitu sel $\beta$ yang terdapat dalam insula langerhans pankreas. Hal ini sesuai dengan penelitian Xiong et al. (2011) yaitu melakukan pengecatan secara imunohistokimia protein GLUT-2 pada islet pankreas.

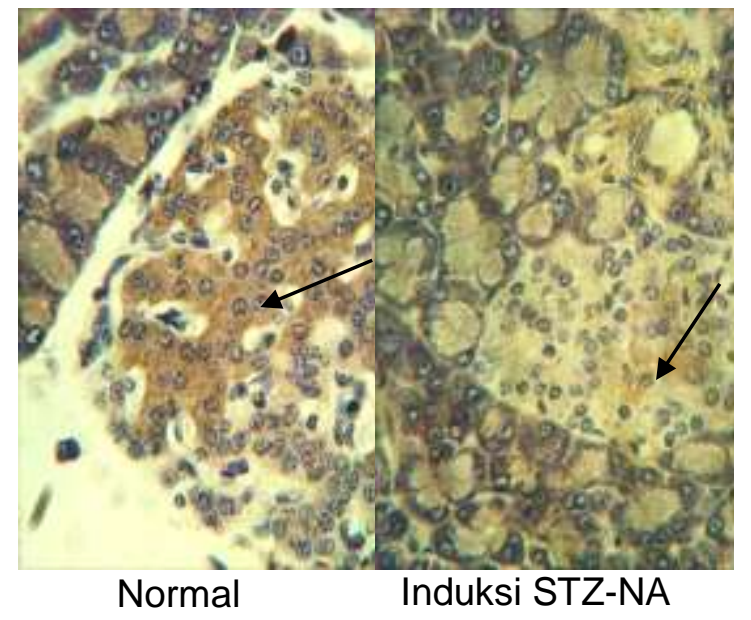

Gambar 1. Hasil pewarnaan imunohistokimia GLUT-2 pada sel $\beta$ pankreas. Tanda panah menunjukkan adanya GLUT-2 pada sel $\beta$ pankreas dalam insula langerhans yang memberikan warna cokelat.

Sel $\beta$ pankreas mensekresikan insulin sebagai respon tingkat glukosa tinggi dalam peredaran darah. GLUT-2 sebagai transporter untuk membawa masuk glukosa sehingga terjadi peningkatan konsentrasi glukosa pada insula langerhans, menyebabkan produksi ATP meningkat, ion Potasium meningkat dan terjadi depolarisasi $\mathrm{Ca}^{2+}$ sehingga sel $\quad \beta \quad$ pankreas mensekresikan insulin (Henquin et al., 2003).
Tabel 1. Hasil rata-rata persentase densitas warna protein GLUT-2 pada sel $\beta$ pankreas secara imunohistokimia

\begin{tabular}{cc}
$\begin{array}{c}\text { Kelompok } \\
\text { Perlakuan }\end{array}$ & $\begin{array}{c}\text { Rata-rata } \\
\text { persentase } \\
\text { densitas warna } \\
\text { protein GLUT-2 }\end{array}$ \\
\hline Normal & 100 \\
\hline Induksi STZ-NA & 32,31 \\
\hline
\end{tabular}

Hasil pengamatan protein GLUT-2 dilakukan dengan menghitung secara semikuantitatif dari densitas warna cokelat pada sel $\beta$ pankreas tikus yang telah dilakukan pengecatan secara imunohistokimia dengan menggunakan antibodi antiGLUT-2. Hasil perhitungan protein GLUT-2 secara semikuantitatif antar kelompok perlakuan dapat dilihat pada gambar 1 .

Pada penelitian ini, ekspresi protein GLUT-2 dinyatakan dalam persentase densitas warna cokelat. Ekspresi protein GLUT-2 menurun pada sel $\beta$ pankreas karena akibat induksi STZ-NA yang menimbulkan toksisitas pada sel $\beta$ pankreas sehingga mengalami kerusakan dan menurunkan sekresi insulin dan meningkatkan kadar glukosa darah, hal ini ditunjukkan pada gambar 1 dimana persentase densitas warna cokelat protein GLUT-2 pada kelompok tikus induksi STZ-NA hasilnya adalah $32,31 \%$. Sebaliknya pada kontrol normal menunjukkan persentase densitas warna cokelat protein GLUT-2 yang tinggi dan dianggap $100 \%$, karena tidak diberikan induksi STZ-NA sehingga tidak 
mengalami kerusakan pada sel $\beta$ pankreas.

Penelitian yang dilakukan oleh Ferrer et al. (1995) yaitu membandingkan ekspresi GLUT-2 pada manusia DM dan tanpa DM. Ekspresi GLUT-2 pada islet pankreas manusia DM tipe II lebih rendah dibandingkan dengan manusia yang tidak mengalami DM tipe II. Penelitian yang dilakukan oleh Arya et al. (2014) bahwa ekstrak Pseudovaria macrophylla pada tikus DM yang diinduksi STZ dan NA dapat menurunkan kadar glukosa darah yang ditunjukkan dengan peningkatan ekspresi GLUT-2 pada sel $\beta$ pankreas.

Sekresi insulin dari sel $\beta$ pankreas merupakan proses kompleks yang melibatkan integrasi dan interaksi berbagai stimulus eksternal dan internal sebagai respon perubahan kadar glukosa darah (Henquin et al., 2003). Secara molekuler mekanisme glukosa menginduksi sekresi insulin melalui beberapa tahapan berikut yaitu peningkatan kadar glukosa diantara sel $\beta$ pankreas, glukosa masuk ke dalam sel $\beta$ pankreas melalui difusi yang difasilitasi oleh protein GLUT-2. Intraseluler glukosa di metabolisme membentuk ATP, mengakibatkan terjadinya peningkatan rasio ATP/ADP dan kadar glukosa darah intraseluler yang tinggi menyebabkan depolarisasi membran sel serta menginduksi penutupan $\mathrm{K}^{+} \mathrm{ATP}$ channel pada permukaan sel, diikuti dengan terbukanya Cell -surface voltage dependent Calsium channels (VDCC), influks $\mathrm{Ca}^{2+}$ ke dalam sel $\beta$, penambahan cytosolic Calsium bebas memicu sekresi insulin, molekul insulin masuk ke dalam sirkulasi darah terikat dengan reseptor. Ikatan insulin dan reseptornya membutuhkan glukosa transporter untuk dapat masuk ke dalam sel otot dan jaringan lemak serta ambilan glukosa dengan efisien, sehingga dapat menurunkan kadar glukosa darah (Henquin et al., 2003).

\section{KESIMPULAN}

Berdasarkan hasil penelitian yang dilakukan dapat ditarik kesimpulan bahwa tikus yang diinduksi STZ-NA dapat menurunkan ekspresi GLUT-2 sel $\beta$ pankreas.

\section{DAFTAR PUSTAKA}

Arya A, Taha H, Khan AK et al. 2014. In vivo antidiabetic and antioxidant potential of Pseudovaria macrophylla extract. International Journal of Medical, Health, Pharmaceutical and Biomedical Engineering 8:514517.

Cavallerano, J. O. D. Ph.D. 2009. Care of The Patient with Diabetes Mellitus.

http://www.aoa.org/documents/ CPG-3.pdf.

Ferrer J, Benito C, Gomis R. 1995. Pancreatic islet GLUT2 glucose transporter mRNA and protein exspression in humans with and without NIDDM. Diabetes 44: 1369-1374.

Henquin JCMA, Ravier M, Nenquin JC et al. 2003. Hierarchy of the beta-cell signals controling insulin secretion. European Journal of Clinical Investigation 33(9):742-750.

Kulkarni CP, Bodhankar SR, Gule AE et al. 2012. Antidiabetic activity 
of Trigonella foenumgraecum $\mathrm{L}$. Seeds extract (ind01) in neonatalStreptozotocin-induced (n-stz) rats. Diabetologia Croatica 41-1: 29-40.

Ohneda M, Johnson JH, Inman LR, Chen L, Suzuki K, Goto Y, Alam $T$, Ravazzola M, Orci L, Unger $\mathrm{RH}$. GLUT2 expression and function in beta-cells of GK rats with NIDDM. Dissociation between reductions in glucose transport and glucosestimulated insulin secretion. Diabetes 1993, 42, 1065-1072.

Ohtsubo KS, Takamatsu MT, Minowa A et al. 2005. Dietary and genetic control of glucose transporter 2 glycosylation promotes insulin secretion in suppressing diabetes. Cell 123(7):13071321.

Rencurel F, Waeber G, Antoine B, Rocchiccioli F, Maulard P,
Girard J, Leturque A. Requirement of glucose metabolism for regulation of glucose transporter type 2 (GLUT2) gene expression in liver. Biochem. J. 1996, 314, 903-909.

Rose AJ, Richter EA. 2005. Skeletal muscle glucose uptake during exercise: how

is it regulated?. Physiology 20(4):260-270.

Xiong X, Wang X, Li B et al. 2011. Pancreatic islet-specific overexpression of Reg3_protein induced the expression of proislet genes and protected the mice against streptozotocin induced diabetes mellitus. $A m \mathrm{~J}$ Physiol Endocrinol Metab 300: E669-E680. 